\title{
GRANDE SERTÃO: VEREDAS, A FORMAÇÃO PELO AMOR
}

http://dx.doi.org/10.11606/issn.2237-1184.v0i28p194-212

Débora Domke Ribeiro Lima

Universidade de São Paulo (USP)

RESUMO

O trabalho propõe ao leitor acompanhar o percurso de formação do protagonista de Grande sertão: Veredas mediante a experiência do amor. Com o objetivo de analisar como esse sentimento promove em Riobaldo o aprendizado, o estudo descortina, por meio da constatação do pacto e pela busca do sentido da vida, seu constante processo de transformação interior.

\section{ABSTRACT}

The work proposes to the reader to follow the course of formation of the protagonist of Grande sertão: Veredas, by the experience of love. With the goal of analyzing how this feeling promotes the learning process in Riobaldo, the study reveals - through the discovery of the faustic pact and the search for the meaning of life -, his constant process of inward transformation.
PALAVRAS-CHAVE:

Amor;

Guimarães Rosa;

Formação;

Pacto fáustico.

\section{KEYWORDS}

Love;

Guimarães Rosa;

Formation;

Faustic pact. 


\section{Por que Grande Sertão: Veredas pode ser considerado um romance de formação?}

Uma breve comparação da obra do escritor brasileiro com Doutor Fausto, de Thomas Mann, pode representar um primeiro passo rumo ao campo temático da formação. $\mathrm{O}$ romance alemão gravita em torno do pactário Adrian Leverkühn, imerso numa atmosfera carregada de sugestões demoníacas. Thomas Mann constrói um personagem que firma o pacto com uma figura demoníaca que, mesmo parecendo residir em projeções da mente do protagonista, interage fisicamente com Adrian.

Já a figura do ser oculto em Grande Sertão: Veredas é revestida da imaginação radicada na cultura popular, trata-se de uma figura essencialmente abstrata, ao contrário da experiência do personagem de Doutor Fausto, que, a seu modo, vivencia o encontro com o diabo. Dessa forma, o pacto promove uma aproximação e, ao mesmo tempo, um distanciamento entre Adrian e Riobaldo. A figuração do demônio, as características próprias dos dois protagonistas e a forma como o pacto foi realizado são fatores determinantes da diferença entre ambos.

$\mathrm{O}$ confronto entre os dois personagens facilita o entendimento da coexistência do amor e do pacto em Riobaldo pela via da formação. A invenção rosiana apresenta ao leitor um narrador permanentemente inacabado e que, num dado momento da história, acredita ter firmado um pacto com o diabo. No entanto, ele guarda em si misturas de sensações, que procura entender e dominar. $\mathrm{O}$ mesmo não acontece com Adrian Leverkühn, que esperava pelo momento no qual pudesse encontrar o demônio, sem dúvidas ou questionamentos sobre seu aprendizado.

O demonismo latente é um ingrediente essencial que determina o "eu" de Leverkühn1. Ele não mantém verdadeiras relações de amizade, nem pode vivenciar o amor. Em Riobaldo, coexiste a mistura das duas entidades opostas, o bem e o mal, evidenciada na ânsia por respostas aos seus questionamentos: "Eu careço de que o bom seja bom e o rúim ruim, que dum lado esteja o preto e do outro o branco, que o feio fique apartado do bonito e a alegria longe da tristeza [...] Como é que posso com este mundo?" 2 . Em seguida, ao comentar a natureza do amigo Jõe

\footnotetext{
${ }^{1}$ Essa afirmação suscita a ideia de que o protagonista de Grande Sertão:Veredas, opondo-se ao caráter imutável de Leverkühn, sofre mudanças interiores, transformando-se por meio de suas experiências.

2 ROSA, João Guimarães. Grande Sertão: Veredas. Rio de Janeiro, Nova Fronteira, 2001, p.237.
} 
Bexiguento, questiona: "por que era que eu também não podia ser assim, como o Jõe? [...] para o Jõe, no sentir da natureza dele, não reinava mistura nenhuma neste mundo - as coisas eram bem divididas, separadas"3.

O processo de formação, portanto, é um aspecto que viabiliza a existência do amor em Riobaldo. As dúvidas que povoam sua mente possuem estreita ligação com as características de um personagem do Bildungsroman (romance de formação), gênero que tem como referência Os Anos de Aprendizado de Wilhelm Meister, de Johann Wolfgang von Goethe, obra com uma construção estética até então inédita no contexto literário alemão.

O clássico goethiano influenciou escritores posteriores, que, de certa forma, afinaram o romance de formação de acordo com a realidade social em que estavam inseridos. Tal fenômeno proporcionou diálogos entre o Bildungsroman clássico e as novas produções literárias, retratando a formação humana sob perspectivas diversificadas. Esse conceito é abordado no livro de Marcus Vinicius Mazzari sobre o romance de estreia de Günter Grass, O Tambor de Lata. O autor aponta para o fato de que os sucessivos desvios que o Bildungsroman vem apresentando em relação ao seu protótipo Os anos de Aprendizado de Wilhelm Meister mostram-se como reflexos das transformações políticas e econômicas ocorridas nas estruturas da sociedade em que o herói em formação busca integrar-se. Se em Goethe a crescente precariedade de tal integração é tratada de forma a se preservar ainda a integridade humana, em outros autores podemos observar uma tendência à dissolução caricatural da concepção clássica de formação ${ }^{4}$.

O romance de formação, portanto, ganha configurações inéditas à medida que novos valores impõem novas necessidades. No entanto, o que interessa para o estudo é esse indivíduo imerso em um contexto histórico-social no qual vivencia sua formação e tem consciência (ou não) desse processo. Esse tipo de romance apresenta o mundo concreto com inúmeros desafios e dificuldades que compõem a formação do protagonista.

Nessa perspectiva, o processo é mais importante que o final, pois existe a preocupação em demonstrar o percurso do "herói", as emoções vividas, o aprendizado proporcionado pelas experiências. Riobaldo apresenta ao seu interlocutor suas transformações, deixa exposto, por meio de seus questionamentos, um ser "aberto", inacabado.

A comparação com Adrian Leverkühn promove, por meio da negação, a caracterização de Riobaldo, podendo-se chegar à conclusão de

\footnotetext{
${ }^{3}$ Ibidem, p.237.

${ }^{4}$ MAZZARI, Marcus Vinicius. Romance de formação em perspectiva histórica, - O Tambor de Lata de Günter Grass. São Paulo: Ateliê Editorial, 1999, p.85.
} 
que o pacto não determinou a malignidade do personagem rosiano. Riobaldo também contrasta com Diodorim, que está próximo a ele e o influencia. $\mathrm{O}$ ser inacabado encontra seu contraponto naquele que o seduz. Como afirma Luiz Roncari, "ao contrário de Riobaldo, sujeito em formação ou 'herói problemático', volúvel, cheio de dúvidas, hesitações, contradições e conflitos, Diadorim já era, estava pronto e acabado, ‘a coragem dele nunca piscava'" 5 .

No primeiro encontro com Diadorim, a travessia aparece de forma concreta. Esse momento deixa transparecer a travessia da vida, em que Riobaldo demonstra, mesmo que a contragosto, suas fraquezas. O mesmo não ocorre com seu companheiro: “'Você nunca teve medo?' - foi o que me veio, de dizer. 'Costumo não..."'6, respondeu o outro. Ao constatar que não era igual ao companheiro e que a diferença o atraía e instigava, o protagonista inicia sua travessia, atravessa a vida provando, errando e experimentando, em um processo no qual vivencia sofrimento e prazer.

Assim acontece com seu comportamento instintivo, que muitas vezes é reprimido em prol de uma atitude aceitável socialmente. $\mathrm{O}$ amor pelo próximo ou até mesmo a constatação de que o instinto poderia destruir a amizade e a gentileza fazem com que Riobaldo reflita sobre suas ações. Em uma passagem na qual o protagonista conta o abuso a que submetia mulheres, demonstra a superação de seu instinto sexual:

E eu era igual àqueles homens? Era. Com não terem mulher nenhuma lá, eles sacolejavam bestidades. [...] Deus me livrou de endurecer nesses costumes perpétuos [...] Contanto que nunca mais abusei de mulher. Pelas ocasiões que tive, e de lado deixei, ofereço que Deus me dê alguma recompensa. $\mathrm{O}$ que eu queria era ver a satisfação - para aquelas, pelo meu ser. [...] Mas o senhor releve eu estar glosando assim a seco essas coisas de se calar no preceito devido. Agora: o tudo que eu conto, é porque acho que é sério preciso ${ }^{7}$.

$\mathrm{Na}$ fala de Riobaldo, percebe-se a mudança interior que essa atitude causou. $\mathrm{O}$ amor ao próximo, nessa ação, supera seu instinto, fazendo com que seu lado mais humano venha à tona8 .

Também não é diferente quando o protagonista deixa-se influenciar pelos ensinamentos de seu mentor Zé Bebelo e do Compadre meu Quelemém. A forte religiosidade que permeia a sua travessia, tanto

\footnotetext{
${ }^{5}$ RONCARI, Luiz. O Brasil de Rosa: mito e história no universo roseano: o amor e o poder. São Paulo: UNESP, 2004, p.227.

${ }^{6}$ ROSA, João Guimarães. Grande Sertão: Veredas. Rio de Janeiro: Nova Fronteira, 2001, p.122.

${ }^{7}$ Ibidem, p.189.

8 É fato que esse "amor ao próximo" não possui uma ausência total de interesse, haja vista a intenção explícita do personagem em receber algo em troca, já que praticou uma boa ação, quando diz: "Pelas ocasiões que tive, e de lado deixei, ofereço que Deus me dê alguma recompensa" (ROSA, 2001, p. 189).
} 
com relação a Deus como ao Diabo, é significativamente intensa.

Compadre meu Quelemém, muitos anos depois, me ensinou que todo desejo a gente realizar alcança - se tiver ânimo para cumprir, sete dias seguidos, a energia e paciência forte de só fazer o que dá desgosto, nôjo, gastura e cansaço, e de rejeitar toda qualidade de prazer. Diz ele; eu creio. [...] E dar tudo a Deus, que de repente vem, com novas coisas mais altas, e paga e repaga, os juros dele não obedecem medida nenhuma ${ }^{9}$.

Além de remeter à cultura popular representada pela simpatia de cumprir a promessa em sete dias, o trecho acima revela certa dose de ingenuidade. Quando ele fala: "Diz ele; eu creio", Riobaldo deixa-se levar pelo próximo, confiando que seu futuro estará em boas mãos. A crença do protagonista é forte e verdadeira, tanto em relação a Deus quanto ao Diabo.

- Você sabe do seu destino, Riobaldo? - ele perguntou. Aí estava ajoelhado na beira de mim.

- Se nanja, sei não. O demônio sabe..." - eu respondi. Me diga o senhor: por que, naquela extrema hora, eu não disse o nome de Deus? Ah, não sei. Não me lembrei do poder da cruz, não fiz esconjuro. Cumpri como se deu. Como o diabo obedece - vivo no momento ${ }^{10}$.

A influência que o personagem sofre provém de diferentes lugares, demonstrando assim a riqueza da cultura popular ${ }^{11}$. Dentro dessa perspectiva, Riobaldo, a partir das experiências e dos ensinamentos recebidos, apresenta uma trajetória que transmite ao leitor uma "evolução pessoal", relacionada não somente com a constatação da mudança interior, como também com a importância do processo de transformação em si.

O romance não apresenta ao leitor um final feliz nos moldes tradicionais; pode-se dizer que há um final reconciliador, uma vez que, por meio da fala, o eu-narrador consegue elaborar sua história de vida, revivendo os principais momentos de sua travessia. Isso implica também a constatação dos medos e das dúvidas vividas e que ainda podem se fazer presentes. Esse aspecto relaciona-se, portanto, ao fato de ele perceber seu percurso, demonstrando o aprendizado vivido ${ }^{12}$.

\footnotetext{
${ }^{9}$ ROSA, João Guimarães. Grande Sertão: Veredas. Rio de Janeiro, Nova Fronteira, 2001, p.169.

${ }^{10}$ Ibidem, p. 212

${ }^{11}$ Esse aspecto é discutido por Leonardo Arroyo em A Cultura Popular em Grande Sertão: Veredas.

12 É necessário ressaltar que essa visão sobre o final reconciliador, concebida na presente abordagem, é apenas uma visão dentre muitas outras. Para o estudioso Willi Bolle em grandesertao.br, a grande questão é a conquista do poder, pois ele passa de jagunço a fazendeiro.
} 


\section{Primeiras transformações do amor}

Nas reflexões de Benedito Nunes em $O$ amor na obra de Guimarães Rosa (1964), o amor se faz presente em Grande sertão: Veredas por meio da vivência de várias formas que oscilam de Nhorinhá a Otacília:

Tenteando de vereda em vereda, de serra em serra, eros em sua perene atividade, impulsiva e sôfrega, mal se detém numa forma, logo abre as asas e prepara-se para voar na direção de outra. [...] $\mathrm{O}$ amor carnal conserva-se no espiritual. Essas duas manifestações, embora qualitativamente distintas, e de diferente altura na escalada do impulso erótico, interpenetram-se, harmonizam-se como as imagens antagônicas de Otacília e Nhorinhá, alcançando o difícil equilíbrio que resulta na superação de uma pela outra13.

O percurso do amor abordado por Benedito Nunes partilha da ideia de formação do indivíduo conforme a concepção goethiana de que “a matéria nunca existe sem espírito, o espírito nunca existe e não pode ser efetivo sem matéria, assim a matéria também tem a capacidade de se elevar, de ascender, assim como o espírito não pode deixar de atrair e de repelir" 14.

Partindo do pressuposto de que o amor é vivido pelo personagem por meio de relações que proporcionam estágios de vivência do sentimento, a experiência do amor de Riobaldo por Diadorim é pautada pela falta, como definido por Sponville em Pequeno Tratado das Grandes Virtudes (1996): “O amor não é completude, mas incompletude. Não fusão, mas busca. Não perfeição plena, mas pobreza devoradora. Ele cabe numa dupla definição: o amor é desejo, e o desejo é falta"15. Otacília e Nhorinhá representam os dois polos pelos quais Ribaldo oscila e que estão misturados em Diadorim.

É possível, portanto, estudar a transformação, a metamorfose do amor, aqui representada pela experiência de Riobaldo e Diadorim, investigando suas nuances ao longo da narrativa ${ }^{16}$. A cada passo da

13 NUNES, Benedito. O amor na obra de Guimarães Rosa. In: Guimarães Rosa. Revisão Ivan Santos de Almeida. Rio de Janeiro: Editora Civilização Brasileira, 1991, p. 147.

14 GOETHE, Johann Wolfgang von. As Afinidades Eletivas. Tradução Erlon José Paschoal, introdução e notas de Kathrin Holzermayr Rosenfield. São Paulo: Nova Alexandria, 1998, p. 48. ${ }^{15}$ SPONVILLE, André Comte. Pequeno tratado das grandes virtudes. São Paulo: Martins Fontes, 1999, p.252.

16 É importante atentar para a relação que existe, na obra, entre sua estrutura e a experiência amorosa. O termo atopia, utilizado por Ettore Finazzi-Agrò, explica essa ligação: "Grande sertão seria atópico pelo fato de identificar um gênero e o seu discurso no mesmo movimento com que todos os gêneros do discurso são por ele revogados, postos em questão, assim como também o sertão rosiano se localiza e se define apenas na perda dos seus limites, na impossibilidade de qualquer localização, no seu estar 'em toda parte'" (2001, p. 93). E aprofunda ainda mais o uso do termo, ao afirmar que "a 'atopia' de Grande Sertão poderia ser vista, nesta perspectiva platônica (e mitológica), também como o efeito deslocante de um Eros (no caso, o amor entre Riobaldo e Diadorim), não conseguindo, todavia, encontrar a passagem para o ato, para a sua 
travessia do protagonista há mudanças interiores significativas que reverberam na tonalidade do amor que sente.

Ao retomarmos o que já foi considerado sobre o protagonista (a convivência do bem e do mal, a configuração apresentada pela figura demoníaca e de seu processo de formação), podemos localizar o foco de sua transformação na experiência amorosa. É fato que, após comparecer ao ritual do pacto, o personagem sofre significativas transformações. Seu companheiro, Diadorim, percebe de imediato:

- [...] você está diferente de toda pessoa, Riobaldo...Você quer dansação e desordem [...] E o que está desmudando, em você, é o cômpito da alma17.

Como forma de facilitar o percurso de análise, optou-se por uma linha de investigação que segue a ordem narrada pelo protagonista em detrimento da cronológica. Só assim poderão ser evidenciados os fatos mais marcantes da vivência amorosa, que contribuirão para o entendimento de suas transformações, uma vez que há uma razão subjetiva para que os fatos sigam a ordem em que foram narrados. Isso é corroborado pelo próprio Riobaldo, quando afirma que "contar seguido, alinhavado, só mesmo sendo coisas de rasa importância. [...] Tem horas antigas que ficaram muito mais perto da gente do que outras, de recente data. O senhor mesmo sabe" 18 .

No início da narrativa, Diadorim confessa a Riobaldo:

'Mas, se você algum dia deixar de vir junto, como juro o seguinte: hei de ter a tristeza mortal...' Disse. Tinha tornado a por a mão na minha mão, no começo de falar, e que depois tirou; e espaçou de mim. Mas nunca eu senti que ele estivesse melhor e perto, pelo quanto da voz, duma voz mesmo repassada. Coração - isto é, estes pormenores todos. Foi um esclaro. O amor, já de si, é algum arrependimento. Abracei Diadorim, como as asas de todos os pássaros. Pelo nome de seu pai, Joca Ramiro, eu agora matava e morria, se bem ${ }^{19}$.

Nas primeiras páginas do livro, portanto, o leitor depara com uma espécie de entrega de Riobaldo ao amor incondicional por Diadorim. Amor este que o faz entrar em uma guerra, assumindo o posto de jagunço, sem hesitar em sua decisão pela vingança do pai de seu companheiro.

Essa constatação aponta para o que se poderia chamar de um processo de formação pelo amor, pois, a partir dele, o protagonista vive

\footnotetext{
realização, isto é, mais uma vez, ficando numa 'aporia' trágica"' (2001, p. 171).

${ }^{17}$ ROSA, João Guimarães. Grande Sertão: Veredas. Rio de Janeiro: Nova Fronteira, 2001, p. 353.

18 Ibidem, p.115.

19 Ibidem, p.56-57.
} 
seu percurso de aprendizagem, experimentado na longa narrativa, e constrói sua própria travessia. Esse aprendizado apresenta inúmeros percalços, demonstra a inconstância, a dúvida e as angústias do protagonista.

O narrador-personagem retrocede no tempo narrado, após declarar sua entrega à guerra por Diadorim e se recorda de quando ainda servia a Medeiro Vaz. Em um episódio no qual escolhe Sêsfredo para acompanhálo até o outro lado do rio para verificar a morte de Santos-Reis, o protagonista, afastado de Diadorim, reflete sobre o que sente de forma ainda incipiente:

Assim e silva, como em outro tempo, adiante, podia flauteado comparecer no Buritís Altos, por conta de Otacília - continuação de amor. Quis não. Suasse saudade de Diadorim? A ponto no dizer, menos. Ou nem não tinha. Só como o céu e as nuvens lá atrás de uma andorinha que passou. Talvez, eu acho, também, que foi juvenescendo em mim uma inclinação de abelhudice: assaz eu queria me estar misturado lá, com os medeiros-vazes, ver o fim de tudo ${ }^{20}$.

O amor por Diadorim é colocado em questão na medida em que se lembra de Otacília. Porém, chega à conclusão de que gostaria de viver mesmo como um jagunço. Não tem certeza de nada, está buscando entender a si próprio, por meio de sucessivos questionamentos e reflexões.

Os três principais amores experimentados por Riobaldo (Diadorim, Otacília e Nhorinhá) são diferentes tipos de amor, sendo o que sente por Diadorim o mais perturbador de todos, devido às complicações impostas pela realidade. Os outros dois, embora não façam parte do enfoque aqui privilegiado, merecem atenção porque interferem na relação de Riobaldo e Diadorim e auxiliam na transformação do sentimento. Benedito Nunes aponta para o fato de que

a relação entre essas três espécies de amor, diferentes formas ou estágios de um mesmo impulso erótico, que é primitivo e caótico em Diadorim, sensual em Nhorinhá e espiritual em Otacília, traduz um escalonamento semelhante ao da dialética ascencional, transmitida por Diotima a Sócrates em $O$ Banquete, de Platão: eros, geração na beleza, desejo de imortalidade, eleva-se, gradualmente, do sensível ao inteligível, do corpo à alma, da carne ao espírito, num perene esforço de sublimação, que parte do mais baixo para atingir o mais alto, e que, em sua escalada, não elimina os estágios inferiores de que se serviu, porque só por intermédio deles pode atingir o alvo superior para onde se dirige ${ }^{21}$.

${ }^{20}$ ROSA, João Guimarães. Grande Sertão: Veredas. Rio de Janeiro: Nova Fronteira, 2001.

${ }^{21}$ NUNES, Benedito. O amor na obra de Guimarães Rosa. In: Guimarães Rosa. Revisão Ivan Santos de Almeida. Rio de Janeiro: Editora Civilização Brasileira, 1991, p.157. 
O aspecto apresentado pelo teórico aponta para um "desejo que se faz anelo" e promove uma espécie de gradação do amor por meio de sua transformação, isto é, para atingir a espiritualidade, o autor mineiro utiliza o corpo, sem, no entanto, excluí-lo quando se atinge o alvo.

Nhorinhá, chamada de "prostitutriz", embora seja uma figura carregada de sexualidade, não é tratada por Riobaldo de forma desrespeitosa: "a mulher-dama apresenta, sempre, um momento de fascínio e encantamento" 22 . Ele se lembra da moça sempre com carinho e de forma pura, pois "a ficção de Guimarães Rosa nos conduz, ainda aqui, a um universo primitivo, onde a mulher-dama, longe de ser vista como impura ou depravada, é uma sacerdotisa do amor - a mulher em que, na realidade, o homem encontra o amor em toda a sua pureza e inocência" 23 .

Há, portanto uma peculiaridade na experiência do amor no autor brasileiro que difere do narrado em $O$ Banquete, uma vez que o amor espiritual é colocado, por Platão, em um plano superior ao carnal. Já em Grande Sertão: Veredas, "o amor carnal gera o espiritual e nele se transforma. [...] Tem o encanto secreto e a sedução da heresia, como força ascendente e descendente, sexo e espírito, que se desenvolve segundo uma dialética imanente".

Retomando o momento da enunciação, depois de encontrar, no caminho de volta, seu amigo estrangeiro Vupes, Riobaldo se refere novamente ao amor, agora já com outra conotação, pois a saudade de Diadorim se faz presente:

Demos no Rio, passamos. E, aí, a saudade de Diadorim voltou em mim, depois de tanto tempo, me custando seiscentos já andava, acoroçoado, de afogo de chegar, chegar, e perto estar. Cavalo que ama o dono, até respira do mesmo jeito. Bela é a lua, lualã, que torna a se sair das nuvens, mais redondada recortada. Viemos pelo Urucúia. Rio meu de amor é o Urucúia ${ }^{24}$.

Nesse momento, o protagonista apresenta ao leitor as primeiras figurações em relação ao amor que guiarão sua vida jagunça. Essa manifestação do amor, que Riobaldo tenta sublimar, mas que retorna de forma pungente, aparece na primeira parte da narrativa, na qual relata sua vida com Medeiro Vaz, a morte desse chefe e a sucessão de Zé Bebelo.

Nesse segmento narrativo, os dois amigos já convivem e experimentam a atração, que adquire múltiplas manifestações, de acordo com suas vivências. Ao retroceder novamente no tempo da narrativa,

${ }^{22}$ LEITE, Dante Moreira. Psicologia e Literatura. São Paulo: Unesp, 2002, p. 110.

${ }^{23}$ Ibidem, p. 112.

${ }^{24}$ ROSA, João Guimarães. Grande Sertão: Veredas. Rio de Janeiro: Nova Fronteira, 2001, p. 89. 
Riobaldo pormenoriza o início dessa história amorosa, quando discorre sobre o primeiro encontro com Diadorim, os dois adolescentes, ocasião ainda em que fizeram a travessia do rio de Janeiro: "Mas eu olhava esse menino, com um prazer de companhia, como nunca por ninguém eu não tinha sentido. Achava que ele era muito diferente, gostei daquelas finas feições, a voz mesma, muito leve, muito aprazível" 25 .

Nesse episódio, especialmente durante a travessia, em que confessa sentir medo, é notória a já mencionada formação pelo amor:

O menino estava molhando as mãos na água vermelha, esteve tempo pensando. Dando fim, sem me encarar, declarou assim: - "Sou diferente de todo o mundo. Meu pai disse que eu careço de ser diferente, muito diferente..." E eu não tinha medo mais. Eu? O sério pontual é isto, o senhor escute, me escute mais do que eu estou dizendo; e escute desarmado. $\mathrm{O}$ sério é isto, da estória toda - por isto foi que a estória eu lhe contei -: eu não sentia nada. Só uma transformação, pesável [grifo nosso]. Muita coisa importante falta nome ${ }^{26}$.

O processo de formação que o irá acompanhar é iniciado no encontro enigmático com Diadorim. O protagonista está entregue ao companheiro, que se torna o ideal de coragem, um ser acabado, contrastando com sua insegurança.

Seguindo a linha narrativa, após a travessia do rio de Janeiro, Riobaldo narra a vida na fazenda de seu tio (pai) Selorico Mendes. É nesse lugar que encontra Joca Ramiro, Ricardão e Hermógenes com o bando, numa noite em que precisam de abrigo para dormir. Ao acompanhá-los até o lugar de descanso, Riobaldo ouve, pela primeira vez, a canção de Siruiz, que tanto o encanta:

Urubú é vila alta,

mais idosa do sertão:

padroeira, minha vida -

vim de lá, volto mais não?...

Corro os dias nêsses verdes,

meu boi môcho baetão:

burití - água azulada,

carnaúba - sal do chão...

Remanso de rio largo,

viola da solidão:

quando vou p'ra dar batalha,

convido meu coração...27 [grifo nosso]

\footnotetext{
${ }^{25}$ ROSA, João Guimarães. Grande Sertão: Veredas. Rio de Janeiro: Nova Fronteira, 2001, p. 119.

${ }^{26}$ Ibidem, p. 125, grifo nosso.

${ }^{27}$ ROSA, João Guimarães. Grande Sertão: Veredas. Rio de Janeiro: Nova Fronteira, 2001, p. 135.
} 
O que interessa para o estudo nessa canção, prenunciadora do futuro de Riobaldo, são os dois últimos versos, que remetem ao "coração" e à "guerra". Como mencionado, o protagonista decide entrar na guerra jagunça por amor a Diadorim, fato narrado no tempo anterior à enunciação e que, ao retroceder na ordem dos acontecimentos, é antecipado pela canção oracular.

Antes de se decidir "por inteiro" a entrar na guerra, vivia incerto sobre o que deveria fazer, se realmente deveria participar da vida jagunça. Não sabia se servia a Zé Bebelo ou a Joca Ramiro, vivendo em constante conflito sobre sua postura ética: “De que lado eu era? Zé Bebelo ou Joca Ramiro? Titão Passos... o Reinaldo... De ninguém eu era. Eu era de mim. Eu, Riobaldo. Eu não queria querer contar" 28 .

Momentos adiante na narrativa, quando reflete novamente sobre sua vida jagunça, fica claro como está perdido e se agarra ao que sente por Diadorim para atribuir sentido à sua vida e decidir sobre seu destino:

Donde eu tinha vindo para ali, e por que causa, e, sem paga de prêço, me sujeitava àquilo? Eu ia-me embora. Tinha de ir embora. Estava arriscando minha vida, estragando minha mocidade. Sem rumo. Só Diadorim. Mas era por não aguentar o ser: se de repente tivesse que ficar separado dele, pelo nunca mais ${ }^{29}$.

Assim, estabelece-se o caráter inexorável do amor: Riobaldo não consegue se separar de Diadorim, seu senso crítico está comprometido pelo arrebatamento que o toma. Nesse estágio do amor, o personagem perde-se de si e não consegue mais se enxergar como um ser único, sua existência só merece sentido na presença do outro, ser que representa a ilusão da completude.

O momento da canção, assim como o do primeiro encontro com Diadorim, é enigmático, pois embora o narrador não tenha consciência da antecipação dos acontecimentos de sua vida, ele experimenta, por meio de sensações, sua importância: “O que me agradava era recordar aquela cantiga, estúrdia, que reinou para mim no meio da madrugada, ah, sim. Simples digo ao senhor: aquilo molhou minha idéia". A vida jagunça está intimamente relacionada ao amor, que aparece de forma clara na canção de Siruiz: o destino do coração de Riobaldo é o de entregar-se na batalha em nome do que sente ${ }^{30}$.

\footnotetext{
${ }^{28}$ Ibidem, p. 167.

${ }^{29}$ Ibidem, p. 197.

30 "Nesse nome (Siruiz) aparentemente sertanejo ressoa o frêmito da busca do amor perdido, tema predileto de cantigas e contos da Idade Média. E o leitor brasileiro, embalado na evidência de que Siruiz é um legítimo jagunço, pode não perceber o sutil jogo de máscaras que mescla, nesse nome, o popular e o erudito, o familiar e o estranho, o próprio e o outro. Sirroohis
} 
No trecho que resume a vida de Riobaldo, o segmento no qual estão condensados os principais acontecimentos, em que o narrador conta, sem divisão em parágrafos, o resumo de sua vida, sintetizando suas principais reflexões, é um momento importante que revela o que a canção de Siruiz antecipa: "Diadorim me veio, de meu não-saber e querer. Diadorim - eu adivinhava. Sonhei mal?" 31 .

O personagem, um pouco mais à frente da narração, pergunta ao companheiro Garanço sobre a canção, confessando que "eu queria saber não era próprio do Siruiz, mas da moça virgem, moça branca, perguntada, e dos pés-de-verso como eu nunca tive poder de formar um igual"32. Esse amor, que toma conta de Riobaldo, ganha dimensões maiores e ocupa um espaço psicológico significativo, mais do que outros setores de sua existência.

\section{Transformação do amor após o pacto}

Depois da morte de Joca Ramiro, Riobaldo deixa a Guararavacã do Guaicuí e parte para o início da obstinada busca por vingança, junto com Diadorim. É nesse momento que as reflexões sobre a existência do demônio e a prenunciação do pacto começam a ecoar: "Eu penso é assim, na paridade. O demônio na rua... Ah, pacto não houve. Pacto?" [grifo do autor] ${ }^{33}$. E já começa a sentir as consequências de sua decisão: "No peso ruim do meu corpo, eu ia aos poucos perdendo o bom tremor daqueles versos de Siruiz?"34.

Ligado a esse aspecto da prenunciação, o protagonista passa a transmitir ao seu interlocutor um lado mais "avesso" de Diadorim: "O ódio de Diadorim forjava as formas do falso. Ódio a se mexer, em certo e justo, para ser, era o meu; mas, na dita ocasião, eu daquilo sabia só a ignorância" ${ }^{35}$. Riobaldo, de certa forma, toma para si o ódio pela morte de Joca Ramiro.

O amor, nesse contexto, é adormecido pelo espírito de vingança que recobre os dois companheiros (embora para Riobaldo haja um espaço para a reflexão sobre a vingança, o que parece não acontecer com Diadorim). Quando estava em combate contra os "hermógenes", na Fazenda dos Tucanos, concentrou-se somente na guerra, voltando-se para

(pronunciado exatamente como siruiz) significa, em armênio, 'meu amor' (quando uma mulher fala do seu amante-homem) e a fórmula plasmou-se numa canção popular de mesmo nome" (ROSENFIELD, 2002, p. 199).

${ }^{31}$ ROSA, João Guimarães. Grande Sertão: Veredas. Rio de Janeiro: Nova Fronteira, 2001, p.137.

32 Ibidem, p.192.

${ }^{33}$ Ibidem, p.328.

${ }^{34}$ ROSA, João Guimarães. Grande Sertão: Veredas. Rio de Janeiro: Nova Fronteira, 2001, p. 332.

35 Ibidem, p. 379. Dessa passagem Walnice Nogueira Galvão, como sabido, extraiu o título de seu importante estudo As formas do falso (São Paulo: Perspectiva, 1988). 
o horror que ela provoca, compadecendo-se de seus companheiros. $\mathrm{O}$ chefe Zé Bebelo ocupa grande parte de seus pensamentos, pois Riobaldo não confia plenamente em sua figura, julgando-o capaz de, a qualquer momento, enveredar pelos caminhos da traição.

Todos esses eventos o afastam, por um período, das reflexões sobre seus sentimentos amorosos. Somente quando chegam ao sítio de Dodó Ferreira é que Riobaldo lembra do amor que sente: "Assim foi que, nesse arraiar de instantes, eu tornei a me exaltar de Diadorim, com esta alegria, que de amor achei" 36 . Mas, mesmo assim, o amor não deixa de apresentar um enfoque negativo: "E tudo neste mundo podia ser beleza, mas Diadorim escolhia era o ódio. Por isso era que eu gostava dele em paz? No não: gostava por destino, fosse do antigo do ser, donde vem a conta dos prazeres e sofrimentos" 37 .

Os desafios do sertão colocam o protagonista em uma posição delicada, ele sente medo. O episódio dos catrumanos, na região do Sucruiú, evidencia sua sensibilidade, e ele se mostra temeroso. "Aqueles catrumanos pedindo por maldição, como era que eu podia deixar de pensar neles? Há-de, que se eles tivessem me pegado sozinho, eu apeado e precisado, decerto me matavam" 38 .

A insegurança irá se apresentar cada vez mais forte na narrativa, levando-o pelos caminhos do pacto, chegando ao ponto de suscitar a busca pelo sentido de sua vida jagunça: “Com Zé Bebelo da minha mão direita, e Diadorim da minha banda esquerda: mas, eu, o que é que eu era? Eu ainda não era ainda. Se ia, se ia" 39 .

$\mathrm{Na}$ busca pelo seu "eu" dissolvido na insegurança, há um personagem que, de certa forma, ajuda-o a construir sua identidade por meio da negação: a figura do Hermógenes, representante da maldade pura, é o indivíduo que constitui aquilo que tendencialmente não faz parte de sua formação. É baseado nele que Riobaldo compõe seu conceito do mal; o que ele sente por seu inimigo é diferente de um rancor comum: "a ofensa passada se perdoa; mas, como é que a gente pode remitir inimizade ou agravo que ainda é já por vir e nem se sabe? Isso eu pressentia. Juro de ser. $\mathrm{Ah}, \mathrm{eu}^{\prime \prime} 40$. E mais à frente, Riobaldo confessa que "o Hermógenes era positivo pactário" 41 .

O protagonista está, portanto, envolvido na busca de sentido do seu "eu" e na concretização do pacto, o que o leva a se afastar, principalmente da figura de Otacília. Não consegue sentir afeto, embora

\footnotetext{
${ }^{36}$ Ibidem, p. 387.

${ }^{37}$ Ibidem, p.393.

${ }^{38}$ Ibidem, p.405.

${ }^{39}$ ROSA, João Guimarães. Grande Sertão: Veredas. Rio de Janeiro: Nova Fronteira, 2001, p.407.

${ }^{40}$ Ibidem, p.410.

${ }^{41}$ Ibidem, p.424.
} 
se esforce; a pungência do pensamento sobre algo iminente não permite isso: "Mas em tanto, com as mudanças e peripécias, no afinco de tudo lhe referir, ditas conforme digo - não toco no nome de Otacília? Nela eu queria pensar, na ocasião; mas mal que, cada vez, achava mais custoso" 42 .

Eis a menção do pacto: "Achado eu estava. A resolução final, que tomei em consciência. O aquilo" 43 . Depois da resolução, ele concretiza o fato nas Veredas-Mortas; porém sem avistar a figura do oculto, somente vivenciando sensações relacionadas a esse universo pactário (o frio, $\mathrm{o}$ tremor e a própria sensação causada pelo lugar). O ser com quem virtualmente firma o pacto é fruto de sua consciência: "Ele tinha que vir, se existisse. Naquela hora, existia" 44.

A tradição fáustica do pacto é notada em alguns comentários feitos pelo narrador: Riobaldo caminha para as Veredas-Mortas, numa noite "friazinha"45. O frio, a escuridão, a encruzilhada são elementos pertencentes à tradição que, no romance, integram o cenário no qual o pactário é um sujeito em formação. Ao contrário do que acontece no pacto tradicional, "o pacto rosiano coloca como problema o sumiço do sujeito ou, pelo menos, de todas as categorias que sustentam tradicionalmente a ideia de um sujeito" 46 .

O protagonista cogita a existência do diabo - "Ele tinha que vir, se existisse. Naquela hora, existia" 47 - e o chama sem obter resposta. Mesmo sem a presença física do diabo, o protagonista tem a sensação de uma transformação: "Meu corpo era que sentia um frio, de si, friôr de dentro e de fora, no me rigir. Nunca em minha vida eu não tinha sentido a solidão de uma friagem assim" 48 .

É com o diabo, fruto de sua imaginação, que Riobaldo acredita ter selado o pacto, para se tornar capaz de enfrentar o Hermógenes: “Eu queria ser mais do que eu"49. Ele é tomado pelo medo: "Medo? Bananeira treme de todo lado" 50 , porém segue seu propósito, tendo em mente que "o que eu estava tendo era o medo que ele estava tendo de mim"51. Vai para o pacto e resvala no nada ou naquele "nonada" que abre o livro.

Ao tomar a decisão de travar o pacto, Riobaldo se preocupa em deixar Diadorim afastado desse evento: "o que eu gostava tanto de Diadorim, tinha um escrúpulo - queria que ele permanecesse longe de

42 Ibidem, p. 426.

${ }^{43}$ Ibidem, p. 434.

${ }^{44}$ Ibidem, p. 436.

45 Ibidem, p. 434.

${ }^{46}$ ROSENFIELD, Kathrin H. "O pacto fáustico em Grande Sertão: Veredas". In: Cienc. Let. N.42 Porto Alegre, 2007, p. 248.

${ }^{47}$ ROSA, João Guimarães. Grande Sertão: Veredas. Rio de Janeiro: Nova Fronteira, 2001, p. 436.

48 Ibidem, p. 439.

${ }^{49}$ Ibidem, p. 437.

${ }^{50}$ Ibidem, p.435.

${ }^{51}$ Ibidem, p.435. 
toda confusão e perigos" 52 .

Imediatamente após a experiência nas Veredas-Mortas, já há manifestação de certa alteração de comportamento. A primeira se dá quando toma consciência de sua necessidade de brigar, instigar a ira dos outros, como forma de prazer: "Figuro de cientificar ao senhor: o costume meu nunca tinha sido esse. Agora, era que eu me espiritava só para arrelias e inconveniências" 53 .

A mudança de Riobaldo no tocante ao amor também se faz sentir logo em seguida, quando tece o seguinte comentário sobre Diadorim:

\begin{abstract}
Daí veio que Diadorim mesmo estranhou aqueles meus modos. A entender me deu, e eu reminiquei, com soltura de palavras: como é que ia tolerar conselho em contradição? Agravei o branco em preto. Mas Diadorim perseverou com os olhos tão abertos sem resguardo, eu mesmo um instante no encantado daquilo - num vem-vem de amor. Amor é assim - o rato que sai dum buraquinho: é um ratazão, é um tigre-leão! 54 .
\end{abstract}

O amor que sente por Riobaldo não impede Diadorim de enxergar as transformações do companheiro, ao contrário, desperta sua sensibilidade, como se aquele fosse uma extensão de si próprio. Trata-se de uma característica desse tipo de amor, que promove a transferência de si no outro, como uma simbiose, causando, inevitavelmente, o sofrimento e a constante angústia de se sentir incompleto longe do ser amado.

Outro fato que corrobora esse aspecto da vivência do amor é o próprio pacto, pois, se o ser amado tem aquilo que o outro não possui, é natural que o amor como falta exija a busca de si no outro e, nesse caso, impulsione o protagonista a tornar-se igual àquele que ama. $\mathrm{O}$ próprio personagem confessa que Diadorim era o "único homem que a coragem dele nunca piscava; e que, por isso, foi o único cuja toda coragem às vezes eu invejei. Aquilo era de chumbo e ferro" 55 .

Pouco depois do pacto, Riobaldo se torna chefe do bando até então liderado por Zé Bebelo, que pela segunda vez deixa o comando. Está entregue à emoção da novidade de sentir-se no poder, mediante a segurança proporcionada pelo ser oculto.

Ao se aproximar mais de Diadorim, igualando-se a ele em coragem, dá mostras de afastar-se de Otacília: "em Otacília, mesmo, verdadeiro eu quase nem cuidava de sentir, de ter saudade. Otacília estava sendo uma incerteza - assunto longe começado"56. A partir do pacto, percebe-se que a ligação entre os dois se torna mais enigmática,

\footnotetext{
52 Ibidem, p.434.

${ }^{53}$ Ibidem, p.443.

${ }^{54}$ Ibidem, p.443.

${ }^{55}$ ROSA, João Guimarães. Grande Sertão: Veredas. Rio de Janeiro: Nova Fronteira, 2001, p. 444.

56 Ibidem, p. 458.
} 
pautada pela linguagem do corpo, principalmente pelos olhos de Diadorim, que guiam as atitudes de Riobaldo. A simbiose do amor tornase mais evidente.

$\mathrm{Na}$ fazenda de Seo Ornelas, quando Riobaldo, com o poder de chefe, fazia a refeição sentado à mesa, desejou a neta de seu anfitrião. A crise de consciência deflagrada pelo impulso de matar o homem para poder desfrutar da moça foi um rompante que quase o tomou. Porém, os olhos de Diadorim intervieram: "os olhos de Diadorim não me reprovavam - os olhos de Diadorim me pediam muito socôrro. [...] E eu também mercês colhi - da alegria veraz, nos meus olhos de Diadorim" 57 . Os olhos de Riobaldo e Diadorim se misturam, formam um único ser. Não há mais retorno: o amor como falta já estava se configurando em seu estágio final, ao encontro da morte.

Ao deixar a fazenda de Seo Ornelas, sem cometer qualquer ato de violência, e chegar à beira do Paracatú, Riobaldo entoa alguns versos de sua autoria. A primeira estrofe, que mais interessa ao estudo, resume a ligação entre o pacto e a transformação do amor:

Hei-de às armas, fechei trato

nas Veredas com o Cão.

Hei-de amor em seus destinos

conforme o sim pelo não ${ }^{58}$

O amor e o pacto estão associados; ele tem consciência da ligação entre os dois e de sua transformação. A negação do pacto é a forma que ele encontra para não entrar em um abismo sem volta, que o espreita sempre diante da dúvida sobre a existência do demônio: "O demo então era eu mesmo?"59.

Diadorim, sem perguntar, somente por meio de atitudes apresentadas pelo companheiro, entende o que se passa e procura as vias religiosas para amparar Riobaldo. O ciúme que antes sentia por Otacília é deixado de lado e pede a ajuda dela para rezar pelo companheiro.

O ciúme cede porque houve a transformação do amor após o pacto, como comenta Riobaldo: "o amor dele por mim era de todo quilate: ele não tartameava mais, de ciúme nem de medo"60. $\mathrm{O}$ amor adquire outra tonalidade, torna-se mais profundo.

É o amor que irá equilibrar a soberba que envolve o agora chefe Riobaldo Urutú-Branco. Em alguns momentos, ele sente a necessidade de exercer o poder: "Onde que então, eu varava mundo, em comando, e ainda não se prezava o meu nome. Eu - o Urutú-Branco! Ser Chefe de

\footnotetext{
${ }^{57}$ Ibidem, p. 474.

${ }^{58}$ ROSA, João Guimarães. Grande Sertão: Veredas. Rio de Janeiro: Nova Fronteira, 2001, p. 479.

${ }^{59}$ Ibidem, p. 487.

${ }^{60}$ Ibidem, p. 498.
} 
jagunço era isso" 61 . O sentimento, no entanto, leva-o para um caminho mais humano: "Abrandei minha lembrança em Otacília, que sincera me aguardasse, em sua casa, em seu meigo estar. Agora eu ia indo às avessas de lá, da Santa Catarina, mas, de arribada, minha intenção de saudade vinha voltando. Tudo, nesta vida, é muito cantável" 62 .

E logo se lembra do amor que o acompanha: "por mesmo de minha vergonha, escondido de mim mesmo eu gostava do cheiro dele, do existir dele, do morno que a mão dele passava para a minha mão. O senhor vai ver. Eu era dois, diversos?" 63 .

Nesse momento, sente-se incapaz de viver o amor; os dois principais de sua vida, Otacília e Diadorim, estão impossibilitados. Não se sente merecedor do amor de Otacília, tão puro, destoante de sua vida pactária, muito menos pode vivenciar o amor de Diadorim, por serem dois jagunços.

A escolha pelo incerto e doloroso, isto é, guiar-se pelo amor, mesmo que de forma não concretizada, faz com que Riobaldo enxergue o mundo pela lente dolorosa do afeto contido. Isso pode ser percebido claramente quando encontra um leproso e não consegue lidar com sua presença, pois o que guarda em si não pode existir em um mundo no qual um ser repugnante habite: "como era que, sabendo de um lázaro assim, eu ia poder prezar meu amor por Diadorim, por Otacília?" 64.

$\mathrm{O}$ amor não admite o que é feio, o que causa repulsa e nojo; fato que remete também à figura do demônio, ser oculto, que, assim como o leproso, esconde-se longe dos olhos de todos, mas está presente, misturado no mundo.

Riobaldo, chefe dos jagunços, atravessa o Liso do Sussuarão, projeto que antes era tido como quase impossível de ser realizado. Após conseguir tal feito, Diadorim, no auge de seu amor, confessa ao amigo: “... Riobaldo, o cumprir de nossa vingança vem perto... Daí, quando tudo estiver repago e refeito, um segredo, uma coisa, vou contar a você..." 65 . No entanto, ele não está afinado com o significado das palavras de Diadorim. Embora os dois tivessem uma sintonia do corpo (em que o protagonista se guiava principalmente pelos olhos do companheiro), havia uma divergência de almas, um afastamento que o colocava longe da verdade que Diadorim pretendia revelar.

Logo após essa passagem, há o episódio com Triciziano e o protagonista tem uma horrível alucinação, vendo o jagunço como o demônio em carne e osso. Seu primeiro impulso, antes mesmo do

\footnotetext{
${ }^{61}$ Ibidem, p. 503.

${ }^{62}$ Ibidem, p. 504.

${ }^{63}$ Ibidem, p. 505.

${ }^{64}$ ROSA, João Guimarães. Grande Sertão: Veredas. Rio de Janeiro: Nova Fronteira, 2001, p. 510.

${ }^{65}$ Ibidem, p. 526.
} 
pensamento, foi o de matá-lo, o que acaba fazendo: "Vi: ele - o chapéu que não quebrava bem, o punhal que sobressaía muito na cintura, o monho, o mudar das caras... Ele era o demo, de mim diante... O Demo!...."66. Isso acontece porque, assim como a presença do leproso era inadmissível, a do Demo também o era.

Depois desse momento, Riobaldo já está a caminho da batalha final contra os Hermógenes, no Paredão. Diadorim, de certa forma, faz com que ele não se esqueça de Otacília. Logo após voltar de uma noite de prazeres com prostitutas, ele lhe pergunta: “`Você já está desistido dela?' - em fim ele indagou. - 'Hem? Hem? Dela quem dela? Tu significa essas velhacas palavras...' - eu só fiz que respondi, redatado"67. O amor perturbado de Diadorim, como um paradoxo, consegue resgatar em Riobaldo o equilíbrio necessário e não o deixa se esquecer do outro amor.

Nesse momento da narrativa, o sentimento que foi se estabelecendo entre Riobaldo e Diadorim já está em estágio final, isto é, o amor transforma-se em um bem-querer, torna-se consciente, o protagonista aceita o que sente e, por fim, o que agora se configura é a sua inexorabilidade; totalmente aceito, esse amor vai tomar seu rumo derradeiro.

Nos momentos finais do livro, o herói retoma sua afeição por Diadorim, transferindo a ele características femininas, sem levantar a hipótese real dessa existência: "Mesmo no escuro, assim, eu tinha aquele fino de feições, que eu não podia divulgar, mas lembrava, referido na fantasia da ideia"68. Ele estava cego, seus olhos não enxergavam o que viam, seu olhar estava além do que via. Somente após a morte do ser amado é que se conscientiza disso, porém está então diante de um fato consumado.

Esse tipo de amor como falta não poderia terminar de forma diferente, pois é irrealizável no plano real. A dor é característica fundamental de sua existência e é traduzida de forma pungente no momento da revelação póstuma do sexo de Diadorim:

\begin{abstract}
Eu estendi as mãos para tocar naquele corpo, e estremeci, retirando as mãos para trás, incendiável: abaixei meus olhos. E a Mulher estendeu a toalha, recobrindo as partes. Mas aqueles olhos eu beijei, e as faces, a boca. Adivinhava os cabelos. Cabelos que cortou com tesoura de prata... Cabelos que, no só ser, haviam de dar para baixo da cintura... E eu não sabia por que nome chamar; eu exclamei me doendo: - Meu amor!...69.
\end{abstract}

A transformação de Riobaldo, guiada pelo percurso de seu amor

\footnotetext{
${ }^{66}$ Ibidem, p. 528.

${ }^{67}$ Ibidem, p. 546.

${ }^{68}$ ROSA, João Guimarães. Grande Sertão: Veredas. Rio de Janeiro: Nova Fronteira, 2001, p. 592.

${ }^{69}$ Ibidem, p. 615.
} 
por Diadorim, permitiu-lhe o aprendizado que se converte em monólogo na tentativa de compreender e elaborar a experiência que ainda o está transformando. As culpas, o medo, a raiva e tantas outras sensações compõem sua travessia e o fazem perceber que o que "existe é homem humano. Travessia"70.

Débora Domke Ribeiro Lima é graduada em Letras pela Universidade Estadual de Londrina (2003); mestre em Estudos Literários pela mesma instituição (2005); e, doutora em Teoria Literária e Literatura Comparada pela Universidade de São Paulo (2013). Participou do Mestrado em Interculturalidade, com bolsa Erasmus, promovido pela Universidade de Tallinn, Estônia (2016). Contato: deboradomke@yahoo.com.br

70 Ibidem, p. 624. 